\title{
Consciousness in the Marxian Conception of History: A Critical Schematization
}

\author{
Michael Sugrue \\ Colunbia University
}

As I read on I discovered that the fellow made no use of mind, and assigned to it no causality for the order of the world, but adduced causes like air and ether and water and many other absurdities . . . That is why one person surrounds the earth with a vortex, and so keeps it in place by means of the heavens, and another props it up on a pedestal of air, as though it were a wide platter.

Socrates, Phaedo 98B-99B

The role of consciousness in history is a fundamental problem for contemporary Marxism, and this is largely attributable to Marx's ambigusus discussion of consciousness and its material concomitants. The persistent tensions in Marx's work between consciousness and matter, idealism and materialism, have nuver been satisfactorily resolved, despite Marx's protestations of "consistent naturalism" and Althusser's attempted distinction between the early and late Marx." Once this is accepted," as Lichtheim observes,

various pseudo problems fall by the wayside, e.g. the question of "what Marx really meant"... it can be shown that in meaning different things at different times (and contradicting himself in the process) he was nonetheless consistent in struggling with a particular set of theoretical and practical problems."

The role of consciousness in history was such a persistent problein for Marx, and in addressing it he addressed a complex of related issues: knowledge and the ideology/science distinction, causality, ethics, method, verifiability and the historical relationship between class structure/consciousness/conflict. Later philosoplers and historians working in the Marxian tradition have extended contradictory elemencs in Marx's treatment of consciousness in history into two general views, which will here be called the linear and the circular. Historical and philosophical criticism will be brouglt to bear on the two views of consciousness as 
they appear in the practice of Marxian historians and phi losophers.

Within Marx's writings, the "linear" view of consciousness is frequently emphasized at the expense of the "circular," but neither position is adopted exclusively. Within the "linear" view, Marx "does not explain practice from the idea, but explains the formation of ideas from material practice." is understood as a dependent variable, a purely contingent epiphenomenal reflex of material life. Ideas, "those phantoins formed in the human brain," are, in this conception

necessarily sublimates of their material life process which is empirically verifiable and bound to material premises. Morality, religion, metaphysics, and all the rest of ideology and their corresponding forms of consciousness no longer retain their seinblance of independence. . . Iife is not determined by consciousness, but consciousness by life."

Passages such as this verge on metaphysical monism by assigning ontological primacy to an Absolute (in this case, the "material life process," i.e. matter), and then positing a relationship of linear, mechanical causality between matter and consciousness."

The basic problem with this linear, strictly materialist view of higtory is that it is empirically falsified. History furnishes us with numerous occasions in which a class behaves in a manner directly contrary to its true material interests, because of certain ideas held by ics members: the readiness of poor, non-slaveholding Southern whites to fight for the Confederacy during the Civil War is one example, and the willingness of the European working class to fight in World War $I$ is another. More damaging still are those instances in which an idea, occurring in the mind of one individual, radically alters the course of history. In what way did Issac Newton's objective relations to the means of production determine his integration of mathematics and physics? And how would European history have developed had his ideas not been promulgated? When the thought of one individual can have such a decisive impact on the concrete practice of so many others, grave questions arise, not only for linear Marxist materialism, but for any political science which purports to schematize future historical developments.

When Marx adopts a "cirular" view, material practice is conceived of as conditioning rather than determining consciousness, and the verb bedingen is generally used in preference to the stronger bestimmen. The circular view allows consciousness a greater degree of autonomy. from material life than the linear. When 
Marx asserts that "it is quite immaterial what consciousness starts to do on its own," " he ascribes to consciousness a remarkable degree of latitude for independent action. Marx does not articulate the circular view systematically, but much of his work presupposes a substantial degree of autonomy for consciousness." To ascribe to consciousness any degree of autonomy from material practice necessitates the invention of novel conceptions of causality, whose unifying characteristic is ambiguity." Consciousness and matter, in this view, have an in(ter)determinate relationship, except "in the last instance," when matter causally determines consciousness. This point is repeatedly made by the later bingels writing against ecunomic determinism. 10

Regardless of whether material practice determines or conditions social consciousness, Marx generally insists that there is an authentic distinction between true and false consciousness, or science and ideology. " Marx understood science as the theoretical reproduction of the real world, a theoretical activity which leads to truth, or practically adequate thought. 22 Although Marx does not use the term ideology in a systematic fashion (Ideen, Anschauungen, Doktrinen are used interchangeably with Ideologie), ideology is always a pejorative term. Ideology may be thought of as necessarily false thought in defense of class interests, the "false consciousness of man alienated from himself by the division of labor." 13 Within Marx's conception of history, during the interval between the initial division of labor and the global proletarian revolution, there must exist a hierarchical class structure of antagonistic producers and exploiters." During periods of social stasis, dominant ideas are coextensive with the ideology of the ruling class, ${ }^{15}$ while during periods of social revolution (when material productive forces contradict the relations of production) rival classes, each with its own ideology, contend for supremacy. '" Class conflict retains an ideological dimension until after the revolution, when ideology will no longer exist, because alienation will no longer exist, because classes will no longer exist. Science will be realized. Man will be redeemed. 27

Marx expects his assertions about history and class consciousness to be persuasive because they are true, which is to say that his premises are scientific and his assertions are the product of the empirical (inductive) method." This begs the question of how the validity of Marxian empixicism and its premises may be determined. Marx appears to pull a metaphysical rabbit out of his hat by asserting that the premises of his empiricism authenticate themselves empirically.

The premises from which we begin are not arbitrary ones, not dogmas, but real premises from 
which abstraction can only be made in the imagination. They are the real individuals, their activity and the material conditions under which they live. . These premises can thus be verified in a purely empirical way.

This obscure passage seems to mean that when an observer is confronted with Marx's premises ("real individuals") about concrete human practice and their verification, his organs of sense will indicate that they are literally, obviously true. One assumes that this demonstration will convince everyone except those unfortunates born without organs of sense and those whose consciousness has been distorted by the ideology of their class. This variety of philosophical deskpounding must strain the credulity of even the most sympathetic reader.

Much of the inconsistency in Marx's conception of history stems from his use of metaphorical speech.20 Three metaphors are essential to Marx's conception of history: "society is an organism;" "society is a building;" "society is a conversation." metaphor "society is an organism" (which reflects the most naturalistic elements in Marx) runs throughout Marx's work, and many subsidiary metaphors are closely related (i.e. "reproduction" of social relations, social "metabolism", "life" of a society). This metaphor has won general acceptance among later philosophers and historjans working in the Marxian tradition.

Marx's later interpreters have not achieved a similar consensus with regard to Marx's other two metaphors. "Linear" Marxists emphasize that "society is a building" while "circular" Marxists stress that metaphorically "society is a conversation." 2 "Society is a building" is advocated by Iinear Marxists, because this "structure," when divided into an "economic base" and an "ideological superstructure," forcefully articulates the primacy of matter and the directly contingent status of consciousness.23 This metaphor was elaborated into a monistic, reductive, mechanical conception of history by Engels,24 Plekhanov, 28 and the theoreticians associated with the second International.2C The events of World War $I$, in which the working classes of each of the most advanced capitalist nations senselessly slaughtered each other to protect the interests of their respective ruling classes, brought inany of the shortcomings of linear Marxism to light. ${ }^{7}$ The linear Marxist position is also logically inseparable from ethical fatalism, which undermines the voluntarism necessary to revolutionary practice. For these and other reasons, 2 circular Marxists, employing the metaphor that "society is a conversation," became increasingly prominent, especially after the October Revolition. Circular Marxists 
view society as an interdeterminative conversation between two contradictory yet interpenetrative elements, consciousness and matter. "This "dialectical" conception of soclety is essentially Hegelian, and it allows consciousness a quasi-autonomous relationship with matter which reflects its idealist origins. Most closely associated with this circular, dialectical Marxism are Lukacs' and Gramsci." Adherents of the building and conversation metaphors interacted dialectically until shortly after the death of Lenin, when all theoretical contradictions were practically sublated and orthodoxy synthesized. Dialectical, circular Marxism was "negated," and its chagrined spokesmen recanted their errors publicly after the counterrevolutionary tendencies of their opinions were empirically verified."2 Stalin's unification of theory and practice determined rather than conditioned the shortcircuiting of interdeterminist Marxism in the U.S.S.R. for the subsequent generation."

Marxism's linear/circular, building/conversation bifurcation was elaborated cutside the U.S.S.R. within the context of a capitalist class structure." Despite this circumstance, both linear and circular Marxists insist that practically adequate thought like their own is possible, while the false consciousness that is an inevitable concomitant of a society divided into classes is to be found not only in "bourgeois ideology" but also, insidiously, within the other, pseudoMarxism. The most formidable institutional bastions of linear Marxism were the U.S. and European communist parties, whose theoreticians unanimously affirmed the reductive, monocausal orthodoxy into which soviet Marxism had ossified. After orthodoxy's death in 1953, linear Marxism came under increasingly heavy ethical, methodological, and epistemological criticism. Linear Marxism retreated under these attacks until Louis Althusser discovered that the real Marx had been a structuralist--a breakthrough which enabled him to define such objections out of existence."

Althusser endorses the defintion of "structuralism" as an "ideology according to which only the relations between the elements (i.e., their places) in the totality are significant, and the occupants of those places are arbitrary."36 This latest and most sophisticated version of linear Marxism ${ }^{37}$ approaches the relation between consciousness and matter by surrounding it with the nultitude of all other relations that obtain in history, where perhaps it will be lost in the crowd. At any rate, it is rarely heard from again: Althusser prefers to focus on the totality of all relations, the "structure of structures," rather than examine any one of them. Althusser asserts that history "is not a text in which a voice (the Logos) speaks, but the inaudible and illegible notation of the effect of a structure of structures." Given that "the whole existence of the 
structure consists of its effects."3s Althusser would like to understand "the determination of the elements of a structure, and the structural relations between those elements, and all the effects of those relations, by the effectivity of that structure. "6" The effects of the structure of structures are determined (you guessed it) by a "structural causality" in which "the comples totality of a structure in dominance is a structure of effects with present-absent causes." 1 Causality might have remained forever mired in the terminological quicksand of Althusser's structuralism had not Balibar (Althusser's theoretical associate) provided the structure with some content: "... the ecollomy is determinant. . ."142

"Consciousness" does not merit extensive treatment, because Althusser believes that "the concept is contaminated by the pre-Marxist ideology of the young Marx." "3 There are, instead, two kinds of "knowledge effects," the scientific and the ideological, which are distinguished by the "mechanisms" that cause ther ("structurally," one would suppose)." Althusserian structuralism's scientific knowledge effect has the unique advantage of verifying itself in an utterly unimpeachable way: history does not validate Theory, Theory validates history." This theoretical immunity from criticism makes Theory the perfect veluicle for legitimizing and consolidating totalitarian political practice." Althusserian structuralism could and did serve to justify the ways of stalin (and could equally well legitimize the reaction to stalin supported by his successors; the names change but the structure does not) to man." Theory is atheodicy."

Circular Marxism is an intrinsically antinomian Weltanschauung which lacks the monolithic unity of the linear conception. Yet the cicrular Marxista," who elaborated Gramsci and Lukacs (after 1935, when Lukacs himself abondoned this position) do share a more or less unified set of theoretical concerns."0 circular Marxism shows a preference for the early (Hegelian) Marx," emphasizes that metaphorically. "society is a conversation," 2 is empirically verified in history, 3 defines consciousness as an essential attribute of any concrete historical class," and attributes to consciousness a (quasi, limited, partial, relative, semi. incomplete) autonomy." The advantage of this conception is that it creates the possibility of a theory of ethics, and thus of politics."

The fundamental difficulty of circular Marxism is the "causal" relationship bewteen consciousness and matter in history." Matter causes consciousiness, consciousness causes matter; each causes the otlier, each causes itself. This causal relationship should not be mistaken for a form of necessity; still less is it a form of contingency. It is neither contingent nor necessary; simultaneously, it is both. ${ }^{\text {s. The con- }}$ 
sciousness of any given class is determined by its objective relation to the means of production, but the consciousness of the individuals composing any given class is not; consciousness is determined in general, not in specific." This causality is not a form of determination at all. It is the comprehensive ambiguity of Marx's conception of consciousness in history, reified.

\section{NOTES}

'Except as noted, all references to Marx refer hereafter to Robert Tucker, ed. , The Marx Engels Reader (New York, 1978, 2nd edition). The quote is from The Economic and Philosophic Manuscripts of 1844, p. 115 .

${ }^{2}$ Louis Althusser, Eor Marx, trans. Ben Brewster (New York, 1969), p. 47 and passim.

'George Lichtheim, Erom Marx to Hegel (New York, 1971), p. 81. This approach seems more sober and judicious than Agnes Heller's, for example: "Like every other thinker of importance, he too refused to sacrifice the search for truth in various directions and along various paths on the altar of coherence. . . the immortality, the living content of Marx's thought - . is based precisely on this brilliant lack of coherence." The Theory of Need in Marx (New York, 1976), p. $87-88$.

'Tucker, ed., The German Ideology, p. 164.

sbid., p. 154-155. It is, incidentally, a matter for speculatiaon what the phrase "material premises" means. Uut of what "material" would one construct premises? A materialist premise (if this is what is meant) would not be "empirically verifiable" because Marxian empiricisin presupposes the Marxian materialism it would then presume to validate.

'Lichtheim argues that Marx did not endorse a reductive monocausal materialism (Erom Marx to Hegel. p. 25), but Marx cannot be absolved entirely. There are many passages from Marx that can legitimately be read as stating that matter determines consciousness. The German Ideology can certainly be read this way: "ruling ideas are nothing more than the ideal expression of the dominant material relationships, the dominant material relationships grasped as ideals." (Tucker, p. 172.) The Introduction to the Preface to the critique of Political Economy is similariy 
reductive: "It is not the consciousness of inen that determines their being, but their social being that determines their consciousness." (Ibid., p.4.)

TTucker, ed., The German Ideology, p. 159.

'This is the case, for example, when Marx states that while revolutionary claso consclousness will necessarily be found among the proletarians, it "may of course arise among other classes too, through the contemplation of the situation of this class." (Ibid.. p. 193.) The idea that some knowledge can be obtained as a pure act of cognition apart from the objective class position of the knower is surely a departure from the determinist conception of class structure and class consciousness, but it does explain Marx himself, who never sold his labor power for a wage.

'To acknowledge this difficulty and to subsequently ignore it will not do. G. A. Cohen, in Karl Marx's Theory of History: A Defence (Princeton, 1978), p.46, dodges the issue in just this way.

10 Tucker, ed., p. 762, Engels-J. Bloch, September 21, 1890: "Marx and I are ourselves partly to blame for the fact that younger people sometimes lay more stress on the economic side than is due it. We had to emphasize the main principle vis à vis our adversaries. who denied $i t$, and we had not always the time, the place or the opportunity to allow the other elements involved in the interaction to come into their rights."

"Although occasionally Marx lapses into outright historicism and thus epistemological relativism. Eor example in Tucker, ed., The Poverty of Philosophy, p. 140: ". . . men, who produce their social relations in accordance with their material productivity, also produce ideas, categories, that is to say the abstract, ideal expression of these same social relations. Thus the cateyories are no more eternal than the relations they express. They are historical and transitory products." Can ore consistently argue this for the ideas and categories of number, cause, time, space, matter? It is understandable that Marxian historicism, and its implicit epistemological nihilism would make Althusser very upset, but it must be noted that his text disrupts his overly neat distinction between the early humanist Marx and the later scientific Marx.

12 See the second Thesis on Feuerbach, Tucker, ed., p. 144 for one clear statement of criterion for truth'. See also Tucker, ed. Economic and Philosophical Manuscripts of 1844, p. 91 for Marx's treatment of than "as an object of natural science." 
"Martin Seliger, The Marxist Conception of Ideology (London, 1977), p. 196.

14 "Hitherto, every form of society has been based as we have seen on the antagonism of oppressing and oppressed classes." Tucker, ed., The Communist Manifesto., p. 483 .

18 "The ideas of the ruling class in every epoch are the ruling ideas." Tucker, ed., The German Ideology, p. 172 .

26 "In considering such transformations a distinction should always be made between the material transformation of the economic conditions of production which can be determined with the precision of natural science, and the legal, political, religious, aesthetic, or philosophic,--in short ideological forms in which men becone conscious of this conflict and fight it out." Tucker, ed., Introduction to the Critique of Political Economy, p. 5 .

1"This whole semblance, that the rule of a certain class is only the rule of certain ideas, comes to a natural end, of course, as soon as class rule in general ceases to be the form in which society is organized, that is to say, as soon as it is no longer necessary to represent a barticular interest as general or the general interest as ruling." Tucker, ed., The German Ideology, p. 174.

"It must be emphasized that Marxian empiricism is a metaphorical, not a literal empiricism. If, for example, a historian and a physicist were both to "empirically" study the Declaration of Independence, their methods would be fundamentally different, and so would their observations. When a historian observes and analyzes a historical text, is he using the same method as a biochemist who observes and analyzes blood? To take empiricism literally would lead to philosophical behaviorism, which would make historical writing and knowledge impossible.

'German Ideology, p. 149.

${ }^{20}$ This is a reason why an analytic of ordinary language reading of Marx is inadequate. Cohen, p. 30 , literalizes the base/superstructure metaphor, thus committing an important category mistake. Cohen's logical rigor is won at the expense of an excessively literalminded interpretation of Marx. See also E. P. Thompson, The Poverty of Theory (New York, 1978), p. 84. 
2'This approach to Marx follows Melvin Rader. Marx's Interpretation of History (New York, 1979). See especially the introduction.

${ }^{22}$ Most Marxists employ both the bullding and conversation metaphors as heuristic devices, but there exists a considerable degree of disparity in the degree to which each is emphasized and endorsed. Circular Marxists tend to be uncomfortable with "linear" metaphors. For example, Eugene D. Genovese (a circular Marxist) has tried to ".. . come to terms with the 'base-superstructure' problem that has plagued Marxism since its inception" by emphasizing that ". . . ideas, once called into being and rooted in important social groups, have a life of their own. "The World the Slaveholders Made (New York, 1969), p. vii.

23 "Base-Superstructure tends to be the model used for the more reductive interpretation." Rader, p. xxi. Base can be conceived without superstructure, but not vice versa.

2"This point is made by Lichtheim, p. 20. See also Friedrich Engels, Anti-Duhring or The Dialectics of Nature for examples of his one-sided, ultra-materialist Marxism.

2"Plekhanov and Lenin invented "dialectical materialism," a term which Marx nowhere uses. See Andrew Rothstein, trans.. G. V. Plekhanov. The Monist View of History (New York, 1972), p. 220 and passim.

2 "Lenin also generally sided with the determinist, reductive Marxists--the "transcript doctrine" of consciousness outlined in Materialism and EmpirioCriticism is the most striking single example of this. Lenin is not consistent, however; the voluntarism of What is to be Done? for exanple does not mesh comfortably with the fatalistic mechanism of his other work.

2 'The divergencies of world history from Marx's own prognostications forced Lenin to attempt a reinterpretation and reexamination. The result was not minor repair but wholesale revision; i.e.. Imperialism, the Final state of Capitalism.

"Less than half of Marx's work had been published prior to 1914. The unpublished manuscripts, which included The Economic and Philosophic Manuscripts of 1844, The German Ideology. are two chief "indeterminist" texts.

"Istvan Meszaros, in "Contingent and Necessary Class Consciousness." p. 87 in Aspects of History and Class Consciousmess (New York, 1972) elucidates the in- 
terdeterminist conception of causality tersely: "In a mechanical conception there is a clear cut line of demarcation between 'determined' and 'determinants.' Not so within the framework of a dialectical methodology. . . although the economic foundations of capitalist society constitute the 'ultimate determinants' of the social being of its classes, these 'ultimate determinants' are at the same time also 'determined deterininants'." What novel meaning is to be attached to the word "ultimate" in this context? When we understand "ultimate" in this way, does the cause/effect distinction still exist? See seliger, p. 44.

${ }^{\circ}$ Georg Lukaćs, History and Class Consciousness is a neo-Hegelian text. See page 61 for example, where class is dafined on the basis of consciousness rather than with reference to its uenber's position in the economic structure. This is the crux of the argument between E. P. Thompson and G. A. Cohen about the criteria for the definition of class. See Cohen, $p$. $73-77$.

"Antonio Gramsci, The Modern Prince and other Writings, trans. Luuis Marks (New York, 1957), p. $\overline{82}$ writes that "the most siynificant philosophical combination that occurred was that in which Marxism was blended with various idealist tendencies, and was regarded by the orthodox, who were necessarily bound to the cultural currents of the last century (positivism, scientism), as an absurdity." Also associated with the introduction of idealist, neo-Hegelian elements into Marxism were Korsch and Bernstein.

${ }^{32}$ Lukacs, in the 1967 preface to History and CJass Consciousness, p. xxviii, gets down on all fours in acquiescing to stalinist criticism of his fiuest book: "these facts meant that I had to rethink my theoretical position. In the debates of the Russian Party I agreed with stalin about the necessity for socialism in one country and this shows very clearly the start of a new epoch in my thought... .

'Llchtheim, p. 67, hits the nail right on the head: ".. . Soviet Marxism is to be understood as a monistic system sui generis, rooted in Engels' interpretation of Marx... ."

"As E. P. Thomson notes," . . I can no longer speak of a single, comnon Marxist tradition, there are two traditions, whose bifurcation and disengagement from each other has been slow, and whose final declaration of irreconcilable antagonism was delayed-as an historical event-until 1956." Poverty of Theory, pp. 188-89. Thompson is substantially correct, but, as has been demonstrated, a single Marxist tradition (set of 
concepts) does not exist even within Marx's own writings. Insofar as a single Marxist tradition has ever existed, its source is in stalin's practice, not Marx's theory.

3s According to Althusser, Marxism is fundamentally opposed to moralism, historicism, humanism, and empiricism. Not only does Theory invalidate such ideological misapprehensions, it also confirms and authenticates itself by establishing criteria for confirmation and authentication which are self-confirming and -authenticating. ". . : theoretical practice is indeed its own criterion, and contains in itself definite protocols with which to validate the quality of its product. . . they have no need for verification from external practices . . . We should say the same for the science which concerns us most particularly: historical materialism." Reading Capital (New York, 1968), p. 59. Thompson is correct in noting that $A 1$ thusser. ilke stalin, is beyond morals, history, or disagreement. Perry Anderson, in Arguments Within Engligh Marxism (London, 1980), p. 105, attempts to exonerate Al thusser from the charge of theoretical stalinism, by referring to the historical facts of Althusser's political activity. It is worth noting that Anderson's argument is based on the "empiricist ideology" which Althusser has invalidated (Reading Capital, p. 105). Althusser, if he is to be defended, must be defended in terms of Theory or not at all.

"Althusser, Reading Capital. p. 319.

"Althusser's anti-Hegelian, scientistic reading of Marx is reductive, deterministic and dogmatic. He reads like Engels without the historicism. Althusser also has a lamentable habit of literalizing his metaphors. See Thompson, p. 104; Althusser, Reading Capital, p. 192 .

"Althusser, Reading Capital, p. 17. It is not coincidental that Althusser was originally raised as a Catholic. If the God of Aguinas was to be conceived of not as a person, but as a "structure," (or a "structure of structures"; a "whole possessing a type of unity quite different froin the type of unity of the spiritual whole," (Reading Capital, p. 107), then God, not being a person, would not have a will; History would then have no telos; thus the Logos would be silent. Althusserian structuralism is High Scholasticism sanded down and varnished with science worship.

"Ibid., p. 189. It is a pity that the word "structure," like the word "effect" and like the word "determination," is never defined. 
"Ibid.. p. 186. Is Althusser not ultimately asking "What causes Everything?" or "How does Everything cause itself?" Althusser pathetically echoes Aquinas' gearch for a Prime Mover within the cosmic indifference. A careful reader of Althusser eventually gets the half awed, half disappointed feeling of walking among the ruins of a cathedral, as if God used to live here bur left some centuries ago.

"Ibid., p. 310. This baroque elocution comes directly from the glossary.

"2Balibar, in Ibid., p. 244. The whole quote is "In different structures, the economy is determinant in that it determines which of the instances of the social structure occupies the deterininant place. Not a simple relation, but a relation between relations; not a transitive causality, but rather a structural causality." The justification for inventing this coinplex, not to say occult causality, beyond the tautological requirements of Althusser's system, is unclear.

"Ibid., glossary, p. 311.

"hIbid., pp. 66-67. Moreover "The ideological knowledge effect is distinguished by its properties (it is an effect of recognition--misrecognition in a mirror connexion) from the scicntific knowledge effect. But insofar as the ideolugical effect, although it depends on other social functions which are dominant in it. really possesses its own knowledge effect, it falls within the general category" (of the knowledge effect).

"We are thus liberated from the empiricist ideology of history. Ibid., p. 105.

"In short, Althusserianism is Stalinism reduced to the paradigm of Theory. It is stalinism at last, theorized as ideology." 'lhompson, p. 182. Paul Anderson, in Arquments Within English Marxism, p. 111 lets Althusser off the hook too easily. As late as 1972, Althusser equated "violent bourgeois antiCommunism" with "Trotskyist anti-stalinism." It is rather late in the day (1976), some 23 years after Stalin's death, that Althusser becomes overtly critical or stalin.

"Lichtheim, p. 145: "Evilly disposed people have been known to hint that Athusser is really after the replaceinent of stalinism with structuralism.. . It has also been suggested that the remedy is worse than the disease, since after all stalinism merely kills the body whereas structuralism destroys the mind." 
"As Seliger notes (p. 197), "ideology purged from
its pejorative meaning (Theory, the scientific knowledge effect) fulfils the function of theodicy. Theodicy justifies by God's infinite wisdom that which appears in the finite perception of man as the shortcomings of the world. Ideology justifies the undeniable evil in revolutionary methods and the visible imperfections of a long established regime or of revolutionary achievements. It does so in reference to the wisdom and goodness either inherent in the existing order as a whole or in one yet to materialize fully.

"In this group are Michael Harrington, E. P. Thompson, Bertell Ollman, John Womack, Wolfgang Leonhardt, Raymond Williams, Melvin Rader, Eugene D. Genovese, Barrington Moore, Jurgen Habermas, Theodore Adorno, Max Horkheimer, Herbert Marcuse, and others.

${ }^{5}$ The central themes of this humanist Marxism (or these humanist Marxisms) are alienation (the false consciousness of man in class society) and the ideological aspect of class relations. See for example Bertell Ollman, Alienation, Marx's Conception of Man in Capitalist society (New York, 1971).

"This is to be contasted with what Thompson (p. 169) calls Marx's "Grundrisse Face," the later mechanistic, determinist Marx.

52 See Rader, Marx's Interpretation of History, p. xxi, also p. 115. See also Thompson, p. $\frac{\text {. }}{9}$.

33 Thompson, p. 47.

stsee Rader, p. 15, and Thompson, Poverty of Theory. p. 46, and The Making of the English Working Class, pp. 9-10. In defining class in terms of consciousness. Thompson clearly shows a debt to Lukacs, $p$. 61 .

"Geuss, Raymond, The Idéa of a Critical Theory (New York, 1981), p. 77. Rader, p. 15, and Thompson, Poverty, p. 96-97: "Yes, yes, and perhaps all this is so. But how might we put such a concept to work? Is law, for example, relatively autonomous, and if so, autonomous of what, and how relatively?"

"Circular Marxism shows its Hegelian origins in denying the Kantian distinction between ethics as a practical and politics as a theoretical doctrine of right. (Thompson, Poverty, p. 175, p. 358) For Hegelians and circularMarxists, there is a theory of ethics as well as politics. Geuss, p. 57, notes of "ideologiekritik" that "the ought is the vught of rationality." As Habermas has said, "I am concerned to 
question . . the separation of science and ethics." (cited in Lichtheim, p. 209.) This idea is essentially Platonic, as is Habermas" "ideal speech situation," which is the platonic dialectic in disguise. For the circular Marxists, as opposed to Althusser, history is a text ill which the Logos does speak. Marcuse, discussing Greek rationalisti, sums the issue up in OneDimensional Man (Boston, 1964), pp. 124-25: "It is the essentially human project. If man has learned to see and know what he really is, he will act in accordance with truth. Epistemology is in itself ethics, and ethics is epistemology." The good is knowable, and to know the good is to do it. In Platonic terms, the Good is True.

'Thompson, Poverty, p. 290: "But because we know the causative context within which an historical event arose, it does not follow that the event can therefore be explained or evaluated in terms of the cause. Attention must be paid to the autonomy of political or cultural events, which, none the less, are causally conditioned by 'economic' events." This conception of causality is too vague for criticism. In the practice of Marxist historians, the refection of mechanism frequently appears to be a rejection of causal necessity. But of course the lack of necessity is not to be confused with contingency. Eugene Genovese's treatment of the U.S. Civil War in The Political Economy of Slavery (New York, 1968), p. 8 is a case in point. Genovese rejects detorminism, and thus the Civil War is held to be probable, not necessary.

"Meszaros, p. 116: "In an objective dialecrical framework of reference, working 'exceptions' constitute the general 'rules', which in an unending interchange, are made into new 'exceptions' and new 'rules', thus both modifying (concretizing) and confirming the general conception itself." If this is the case, Marxism can predict the outcome of current political events; they will manifest a general tendency toward the classless condition (the Marxian idea of progress) or they will have some other quality or qualities, which can be integrated back into theory, which will retroactively confirm that theory was not wrong, just incomplete. "Exceptions to the 'iules' which Marxian history lays down" do not falsify the propositions of which this conception of history are cumpused; these propositions are not, in principle, falsifiable.

sollman, pp. 124-26 engages in an astonishing series of intellectual contortions in the course of attempting to salvage a consistent relationship between consciousness and its material concomitants. When the consciousness of an individual is radicaliy different from others whose objective relarions to the means of 
production are identical, the cause is "personal life": "It is a matter of family, friends, and one's very place on the earth each moment of the day. This is the area of human existence which Marx stakes out, without too much precision, as the 'personal life'. On occasion the conditions operating in this area are sufficient to overturn the results that naturally flow from one's activity in the mode of production, and the class relations based upor it." This appears to mean that a man whose consciousness is radically different from what is typical of people whose relations to the social means of production are identical with his, has a "personal life," and thus his consciousness is atypical because of his personal life. It might, with equal logical justification, be argued that a man whose consciousness is typical for his class also has a personal life, and thus his consciousness is typical because of his personal life. This new construct, "personal life," thus explains all manifestations of human consciousness, and since "personal $11 \mathrm{fe}$ even explains those cases, like Newton, which "class" could not, Ollman has implicitly succeeded in showing that the concept of class is more or less superfluous now that it is meaningful to explain consciousness in terms of "personal life." One cannot help but suspect that ollman's consciousness of his unigue insight was determined not by his "personal life" but by the logical necessity of explaining away the incomplete correlation between consciousness and class. 